\title{
AZJA POLUDNIOWO-WSCHODNIA
}

\section{Krzysztof Szumski}

\section{AZJA POŁUDNIOWO-WSCHODNIA W POLITYCE USA: NOWE ROZDANIE}

\section{Sytuacja w Azji Wschodniej na przełomie lat 2016/2017}

\section{Nowe zjawisko $w$ regionie}

Od początku drugiego dziesięciolecia XXI w. w Azji Wschodniej pojawiło się i stopniowo nasilało nowe zjawisko - konkurencja, a następnie narastająca rywalizacja chińsko-amerykańska. Miała ona najczęściej charakter dyskretny, mało widoczny dla mniej uważnych obserwatorów, czasami jednak nabierała cech niemal frontalnej konfrontacji wielkich mocarstw światowych. Wszystko to działo się niezależnie od różnych wydarzeń na płaszczyźnie stosunków chińsko-amerykańskich, mogących świadczyć o dobrej atmosferze wzajemnych relacji. Ceniony ekspert do spraw stosunków chińsko-amerykańskich David Shambaugh uważał w połowie 2015 r., że relacje obu krajów weszły już w etap, w którym rywalizacja zaczyna przeważać nad współpracą i obejmuje wszystkie dziedziny stosunków, różnice stanowisk zaś są głębokie i trudne do pogodzenia, a każdy incydent, szczególnie na morzach okalających Chiny i w pobliżu Tajwanu, grozi bardzo poważnymi konsekwencjami ${ }^{1}$.

\section{Rywalizacja koncepcji}

Na przełomie pierwszego i drugiego dziesięciolecia XXI w. pojawiły się dwie wielkie koncepcje handlowo-gospodarcze obejmujące region Azji i Pacyfiku, w pewnym, choć w różnym stopniu włączające obszar funkcjonowania ASEAN. Pierwsza to Trans-Pacific Partnership - TPP, druga to Regional Comprehensive

${ }^{1}$ David Shambaugh, In a Fundamental Shift, China and the US Are Now Engaged in All - Out Competition, „South China Morning Post”, 11 czerwca 2015. 
Economic Partnership - RCEP. Poza kwestiami merytorycznymi w obu tych projektach istotą różnic było przede wszystkim to, że proponowały odmienną organizację regionu i de facto promowały dwie różne sfery wpływów i role dwóch supermocarstw - USA i Chin.

Od 2012 r. obie koncepcje znalazły się w centrum debaty integracyjnej w regionie Azji i Pacyfiku. Należy odnotować, że RCEP opierał się w dużej mierze na wykorzystaniu istniejących porozumień handlowych, negocjowanych i zawieranych przez ASEAN z dużą liczbą partnerów w regionie i na zewnątrz, natomiast TPP stanowiło inicjatywę całkowicie nową. Inny też był zakres geograficzny obu projektów. O ile TPP grupował dwanaście krajów z obu brzegów Pacyfiku, w tym z ASEAN Malezję, Wietnam, Singapur i Brunei, a także Australię, Nową Zelandię, Peru, Chile, Japonię, Kanadę, Meksyk oraz USA (główny rozgrywający), ale bez Chin, to RCEP obejmował cały ASEAN oraz sześć krajów: Chiny, Koreę Południową, Japonię, Indie, Australię i Nową Zelandię, a więc bez USA. Przy czym propozycję zgłosiła Indonezja, ale z wyraźnej inspiracji Chin.

O ile RCEP proponował bardziej klasyczne i ograniczone rozwiązania z zakresu ułatwień handlowych, o tyle TPP był projektem ambitniejszym, bardziej przemyślanym i w dużym stopniu nowatorskim, a jego cele jasno określił prezydent Barack Obama w „Washington Post” z 22 stycznia 2015 r.: „Jeżeli to nie my ustanowimy reguły, to ustalą je w regionie Chiny zamiast nas. My będziemy z tego wyłączeni”. Czyli miała to być nowa wersja przynajmniej części reguł światowego ładu (liberalnego), stworzonego i kontrolowanego przez Stany Zjednoczone.

W wyniku lobbystycznej działalności USA, a czasem bezwzględnych i brutalnych nacisków, konkurencyjny dla Chin projekt TPP został ostatecznie uzgodniony pod koniec 2015 r. i podpisany 4 lutego 2016 r. przez wspomniane dwanaście państw. Do jego wejścia w życie brakowało ratyfikacji przez parlamenty tych państw, a przede wszystkim przez Kongres Stanów Zjednoczonych.

W miarę rozwoju kampanii prezydenckiej w USA i rosnących szans Donalda Trumpa przyszłość TPP, którego kandydat na prezydenta stał się zdecydowanym krytykiem, zaczęła rysować się coraz mniej optymistycznie, tym bardziej że i Hillary Clinton, choć prawdopodobnie z powodów taktycznych, zaczęła wypowiadać się o TPP krytycznie. Zwycięstwo Trumpa oznaczało koniec TPP, przynajmniej w jego obecnym kształcie. Wstrzymano zatem realizację porozumienia, ale przede wszystkim, przynajmniej na jakiś czas, odłożono amerykańskie projekty nowego unormowania szeroko rozumianego handlu i współpracy gospodarczej w regionie, a nawet szerzej, w świecie. Prezydent Trump 23 stycznia 2017 r. podpisał dekret o wycofaniu się USA z TPP. Otworzyło to pole dla innych inicjatyw regionalnych, przede wszystkim tych wspieranych przez Chiny, jak RCEP czy handlowe porozumienie trójstronne Chin, Japonii i Korei Południowej. Chiny zechcą zapewne 
także powrócić do idei Free Trade Area of the Asia Pacific, czyli FTA dla regionu Azji i Pacyfiku (FTAAP)².

Wycofanie się USA z TPP wiąże się ze znacznym osłabieniem polityki pivot, czyli rebalance, realizowanej przez Baracka Obamę w regionie. Pivot bez swojego komponentu gospodarczego, wobec dynamiki ekspansji gospodarczej Chin w regionie, traci na efektywności i przestaje być skuteczny dla powstrzymywania działań Pekinu.

\section{Nowe tendencje w Azji Południowo-Wschodniej}

Ogólny rozwój sytuacji w samej Azji Południowo-Wschodniej w 2016 r. wydawał się także sprzyjać raczej umocnieniu pozycji Chin. Nastąpiła korzystna dla nich ewolucja polityki zagranicznej Filipin i Malezji. Wietnam, po entuzjastycznym przyjęciu wizyty Obamy w pierwszej połowie roku, widząc przebieg kampanii prezydenckiej w USA, stał się jeszcze ostrożniejszy i unika jakichkolwiek zadrażnień z Chinami. Równocześnie Singapur i Indonezja okazały się nieco bardziej wstrzemięźliwe w relacjach z Chinami, sygnalizując większe zainteresowanie stosunkami z innymi silnymi partnerami, zwłaszcza z Japonią i Indiami, a przede wszystkim z USA. Tajlandia tradycyjnie prowadziła politykę lawirowania pomiędzy USA i Japonią a Chinami, ale sankcje amerykańskie związane z przejęciem władzy przez wojskowych popychały ją w kierunku Chin. Pewnym wsparciem dla pozycji amerykańskich była silna aktywizacja w sferze międzynarodowej, zwłaszcza w regionie Azji Południowo-Wschodniej, Japonii, i to zarówno na płaszczyźnie gospodarczej, jak i (co jest nowością) politycznej. Premier Shinzō Abe odbył serię wizyt w regionie, mających wyraźnie na celu blokowanie wpływów chińskich w okresie, kiedy aktywność amerykańska w związku z kampanią prezydencką była znacznie osłabiona.

Z kolei działania Pekinu koncentrowały się przede wszystkim na dalszym promowaniu inicjatywy OBOR (One Belt, One Road), w tym szczególnie ważnego dla regionu „Morskiego Jedwabnego Szlaku XXI wieku”, oraz na przystąpieniu do praktycznego działania takich instytucji jak Azjatycki Bank Inwestycji Infrastrukturalnych (AIIB), który ukonstytuował się w styczniu 2016 r., Nowy Bank Rozwoju (NDB) utworzony przez kraje BRICS w lipcu 2015 r., który na początku 2016 r. zaczął udzielać kredytów, a także specjalny Fundusz Jedwabnego Szlaku, utworzony w grudniu 2014 r. i wspierany przez chińskie banki, takie jak China EximBank i China Development Bank oraz fundusze inwestycyjne.

W maju 2017 r. odbyło się organizowane przez Chiny Forum Międzynarodowe z udziałem przywódców 29 państw zaangażowanych w OBOR, które miało nadać

${ }^{2}$ Zhang Yunbi, Chen Weihua, Beijing To Push Talks on Regional Free Trade Pacts, „China Daily", 25 stycznia 2017. 
nową dynamikę wszechstronnej współpracy wzdłuż różnych tras szlaku, a w praktyce ekspansji handlowej i inwestycyjnej Chin, ale także wzmocnić polityczne oddziaływanie Pekinu na olbrzymim obszarze Eurazji, Bliskiego Wschodu i dużej części Afryki Wschodniej. W forum licznie uczestniczyli przywódcy państw Azji Południowo-Wschodniej, co potwierdziło atrakcyjność oferty chińskiej, ale i rosnące związki z Pekinem.

\section{Zapowiedzi i konkretne działania głównych graczy w Azji Wschodniej}

\section{Azja Wschodnia w kampanii wyborczej i w początkach prezydentury Donalda Trumpa}

W zapowiedziach wyborczych Donalda Trumpa Chiny wyrosły na głównego przeciwnika, przede wszystkim ekonomicznego, ale również w aspekcie politycznym i militarnym. Szczególnie niepokojące było podanie w wątpliwość zasady ,jednych Chin”, między innymi po rozmowie telefonicznej z prezydent Tajwanu Tsai Ing-wen w grudniu 2016 r. Drugim wydarzeniem o istotnym znaczeniu i o podobnej wymowie była późniejsza nominacja Petera Navarro na szefa nowego organu administracji - Rady Handlu Narodowego. Navarro jest uważany za wielkiego przyjaciela Tajwanu i zwolennika rozwijania z nim stosunków. Zarówno Trump, jak i Navarro wielokrotnie nazywali Chiny „manipulatorem walutowym” i twierdzili, że dzięki takim krokom Chiny zalewają rynek amerykański swoimi towarami. Zapowiadali drastyczne ograniczanie importu z Chin poprzez wprowadzenie wysokich ceł (nawet do 45\%).

Stopniowo jednak, szczególnie po oficjalnym objęciu przez Trumpa fotela prezydenta, pojawiało się wiele innych sygnałów wskazujących wyraźnie, że relacje z Chinami będą dla ekipy Trumpa priorytetowe, ale też staną się przedmiotem koniecznej refleksji oraz zachowania ostrożności i rozwagi. Później okazało się, że także płaszczyzną zaciętej rywalizacji różnych grup doradców prezydenta oraz nie do końca jasnych kontaktów biznesowych jego najbliższego otoczenia z chińskimi partnerami.

Pierwszym sygnałem, że zapowiedzi nowej ekipy ostrej polityki wobec Chin należy traktować ostrożnie, była nominacja na nowego ambasadora USA w Pekinie, Terry' ego Branstada, gubernatora stanu Iowa. Branstad uważany jest za przychylnego Chinom i ma tam świetne kontakty, w tym zna samego prezydenta Xi Jinpinga ${ }^{3}$.

Kolejnymi sygnałami były wycofanie się Trumpa z kwestionowania tak zwanej polityki ,jednych Chin”. Nastąpiło to w rozmowie telefonicznej z chińskim

\footnotetext{
3 Justyna Szczudlik, Chińska perspektywa stosunków z USA za prezydentury Donalda Trumpa,
} „Biuletyn PISM”, 16 stycznia 2017, nr 4. 
kolegą Xi Jinpingiem, w której, jak głosił komunikat, ,prezydent Trump na życzenie prezydenta Xi zgodził się respektować tę politykę"4. Wreszcie 27 lutego 2017 r. Trump przyjął w Białym Domu wysłannika Xi Jinpinga, radcę państwowego (odpowiednik wicepremiera odpowiedzialny za sprawy zagraniczne) Yanga Jiechiego. W spotkaniu uczestniczyli także wiceprezydent Mike Pence i starszy doradca w gabinecie prezydenta Jared Kushner (zięć Trumpa). Yang spotkał się również z głównym strategiem urzędu prezydenta Stephenem Bannonem oraz z doradcą do spraw bezpieczeństwa H.R. McMasterem, a następnie z sekretarzem stanu Rexem Tillersonem. W tej ostatniej rozmowie strony podkreśliły znaczenie wcześniejszej rozmowy telefonicznej $\mathrm{Xi}$ - Trump, ustaliły wejście w nową fazę rozwoju wzajemnych stosunków i zapowiedziały dalsze intensywne kontakty, w tym na najwyższym szczeblu. Wizyta Yang Jiechi odbyła się w 45. rocznicę historycznej wizyty prezydenta Nixona w Pekinie z roku 19725. W duchu rozmów Yanga odbyło się spotkanie chińskiego ministra spraw zagranicznych Wang Yi z Rexem Tillersonem na początku marca przy okazji spotkania ministrów spraw zagranicznych G20 w Niemczech. W wyniku spotkania Tillerson w połowie marca odwiedził Pekin. Wizyta, w czasie której został przyjęty przez prezydenta Xi Jinpinga, pozwoliła na wymianę poglądów, ale bez poruszania dzielących oba kraje problemów, w tym sytuacji w Azji Południowo-Wschodniej. Jak podaje strona chińska, Xi podkreślił między innymi, że USA i Chiny o wiele więcej łączy, niż dzieli. Również Tillerson wysoko ocenił kontakt z chińskim przywódcą i mówił o rozwoju w przyszłości stosunków amerykańsko-chińskich.

Już wtedy, jak się wydaje, można było zaryzykować ocenę, iż powyższe sygnały wskazują, że przy prawdopodobnych dalszych zmianach i pewnym zaostrzeniu polityki amerykańskiej wobec Chin - zwłaszcza w sferze handlu i współpracy gospodarczej - intensywny dialog supermocarstw będzie podtrzymany, a nawet rozwijany.

\section{Postawa Chin}

W Pekinie prezydenckie zwycięstwo Trumpa przyjęto spokojnie. Wiele jego ostrych wypowiedzi na temat stosunków amerykańsko-chińskich uznano za mało istotną wyborczą retorykę. $\mathrm{Z}$ nieukrywanym niepokojem odnoszono się wyłącznie do perspektywy relacji handlowych, mając między innymi na uwadze niedawną odmowę administracji Obamy przyznania Chinom „statusu gospodarki rynkowej" (MES). W sferze politycznej uważano, że polityka Trumpa będzie o wiele mniej ideologiczna, czyli znacznie mniej zaangażowana w próby oddziaływania na

${ }^{4}$ Paris Gilles, Donald Trump se rallie à la politique d'une seule Chine, „Le Monde”, 10 lutego 2017.

5 Zhao Huanxin, Trump Holds First Meeting With Senior Chinese Official, „China Daily”, 28 lutego 2017. 
sposób rządzenia i funkcjonowania władz i społeczeństwa w Chinach, niż mogłoby to być w przypadku zwycięstwa Hillary Clinton. Oceniano z zadowoleniem, że skończył się okres intensywnego lansowania modelu zachodniej liberalnej demokracji ${ }^{6}$. Uznano także, że odejście od realizacji TPP osłabia i stawia pod znakiem całą politykę pivot, a w praktyce politykę „powstrzymywania” Chin w regionie oraz otwiera nowe duże możliwości dla inicjatyw chińskich w regionie.

Prawdziwym szokiem dla Chin był jednak krótki okres, kiedy wydawało się, że Trump faktycznie odrzuca politykę ,jednych Chin”. Wypowiedzi chińskich polityków były wówczas bardzo ostrożne i wyważone, ale nie pozostawiały miejsca na wątpliwości, że sprawa jest niezwykle poważna i prowadzi do pełnej konfrontacji. Media chińskie reagowały o wiele bardziej nerwowo. Wyjaśnienie sprawy, w sumie zgodne ze stanowiskiem chińskim, po rozmowie telefonicznej obu prezydentów ponownie wprowadziło wyraźne uspokojenie nastrojów w Chinach, szczególnie wśród komentatorów w mediach.

\section{Japonia włącza się do gry}

Wybór Trumpa był również zaskoczeniem dla Japonii, gdzie olbrzymia większość obserwatorów przewidywała zwycięstwo Hillary Clinton. Premier Shinzō Abe i jego otoczenie zademonstrowali pragmatyzm i, niezależnie od tego, co mówił Trump w kampanii wyborczej na temat ich kraju, podjęli natychmiast energiczne działania w celu nawiązania bezpośredniego dialogu z prezydentem elektem. Shinzō Abe doskonale rozumiał, że bezpieczeństwo Japonii nadal bezpośrednio opiera się na sojuszu z USA, a w praktyce zależy od obecności około 54 tys. żołnierzy amerykańskich na terytorium jego kraju. $Z$ jednej strony intensywniej przypominano różnymi kanałami amerykańskim partnerom, że nawet przy pełnym wyliczeniu wszystkich kosztów pobytu sił USA Japonia pokrywa aż 75\% tej sumy, co jest wyjątkowo wysokim wskaźnikiem wśród amerykańskich sojuszników ${ }^{7}$. Z drugiej japoński premier był pierwszym szefem rządu, który spotkał się z prezydentem elektem (17 listopada 2016), co pozwoliło na nawiązanie przyjaznego kontaktu i stworzenie dobrego klimatu dla dalszych rozmów.

Mimo że Japonia miała być jednym z beneficjentów umowy TPP, premier Abe nie podjął, przynajmniej na razie, propozycji niektórych członków TPP (na przykład Australii czy Meksyku), aby organizować się bez udziału USA. Uznał sprawę za zamkniętą (nieco później Japonia zgodziła się jednak uczestniczyć pod koniec maja 2017 r. w spotkaniu przedstawicieli 11 państw sygnatariuszy TPP). Jego

${ }^{6}$ Minxin Pei, Trump’s Rise Leaves China Ideologically Safe but Facing Graver Security Risks, „South China Morning Post”, 12 lutego 2017.

7 Eduard Pflimlin, Tokyo paie beaucoup plus que ne l'imagine Trump pour son alliance avec les Etats - Unis, „Le Monde”, 17 listopada 2016. 
działania koncentrowały się na dalszym poszukiwaniu swego rodzaju nowej asekuracji ze strony potężnego sojusznika, ale także na już wspomnianej bardzo wysokiej wszechstronnej aktywności w regionie.

Jeżeli chodzi relacje z USA, bardzo ważnym momentem była wizyta w Japonii na początku lutego 2017 r. nowego sekretarza obrony Jamesa Mattisa, który zapewnił o trwałości sojuszu i zaangażowaniu USA w obronę Japonii, w tym w obronę wysp Senkaku/Diaoyu, a także w obronę przed ewentualnymi agresywnymi działaniami Korei Północnej, zgodnie z porozumieniem między oboma krajami. Podobne deklaracje sekretarz obrony USA złożył w Seulu wobec władz Republiki Korei. Shinzō Abe kontynuował swoje działania wobec nowej administracji. W połowie lutego złożył kolejną wizytę w USA i spotkał się z Donaldem Trumpem już jako zaprzysiężonym prezydentem (tutaj ubiegła go tylko premier Wielkiej Brytanii Theresa May). Premier wystąpił wobec Trumpa z pozytywnym przesłaniem, przedstawiając cały pakiet interesujących propozycji współpracy gospodarczej, w dużym stopniu opartej na japońskich inwestycjach w USA. Shinzō Abe wyraźnie postanowił wykorzystać probiznesowe nastawienie nowego prezydenta i jego plany ożywienia gospodarki amerykańskiej. Propozycje japońskie koncentrowały się na pięciu kierunkach: rozbudowie i modernizacji infrastruktury, robotach przemysłowych, sztucznej inteligencji, cybernetyce i badaniach kosmicznych oraz na technice wojskowej. Duża część miałaby być finansowana przez stronę japońską między innymi ze środków Funduszu Emerytalnego. W pewnych sformułowaniach propozycji japońskich można odnaleźć sugestie wspólnych działań na polu gospodarczym przeciwko Chinom $^{8}$. Najważniejsze było jednak to, że Trump, przyjmując Shinzō Abe, potwierdził niedawny przekaz sekretarza obrony Mattisa dotyczący zaangażowania USA w sojusz z Japonią, w tym pełne poparcie dla utrzymania obecnego statusu wysp Senkaku/Diaoyu na Morzu Wschodniochińskim.

W świetle powyższego można już ocenić, że Japonia dzięki aktywnej polityce premiera Shinzō Abe potrafiła w dużym stopniu zneutralizować możliwe pierwsze negatywne wpływy zmian na stanowisku prezydenta USA na swoją pozycję w regionie Azji Wschodniej.

${ }^{8}$ Maria Kruczkowska, Tokio uktada się z Donaldem Trumpem, „Gazeta Wyborcza”, 7 lutego 2017. 


\section{Elementy nowej sytuacii w regionie Azii Południowo-Wschodniej}

Stanowisko nowej administracji USA wobec Azji Południowo-Wschodniej

W okresie kampanii wyborczej i później jako prezydent elekt Donald Trump kilka razy zabrał głos w sprawie niektórych aspektów sytuacji w regionie, wypowiadali się na ten temat również członkowie jego ekipy rządowej.

Trump między innymi wypowiedział się przeciwko „chińskim ambicjom terytorialnym na Morzu Południowochińskim" i określił działania Chin na tym obszarze jako budowanie potężnej fortecy, co miałoby rzekomo świadczyć o braku szacunku dla USA. W podobnym duchu wyraził się też Mike Pence ubiegający się o stanowisko wiceprezydenta. Trump zapowiedział ponadto, że USA poprzez nacisk w sferze handlu powinny zmusić Chiny do zaprzestania takich działań ${ }^{9}$. Znacznie dalej poszedł Rex Tillerson, który w czasie senackiego przesłuchania na stanowisko sekretarza stanu powiedział, że można i należy przeszkodzić Chinom w dostępie do ich instalacji na sztucznych wyspach na Morzu Południowochińskim. Amerykańscy obserwatorzy sytuacji w regionie jednoznacznie ocenili, że niezależnie od odejścia od TPP należy przygotować się na sytuację znacznie mniej stabilną i mniej przewidywalną. Za prawdopodobne uznali również nasilenie się w regionie wyścigu zbrojeń i wzrost obecności wojskowej.

Pod koniec lutego 2017 r. na Morze Południowochińskie wpłynęła amerykańska grupa bojowa z lotniskowcem USS „Carl Vinson” (klasa Nimitz) w celu realizacji „rutynowej misji” na tym akwenie, w tym operacji w ramach zapewnienia „wolności żeglugi". Wzrosła również liczba lotów patrolowych samolotów amerykańskich w regionie. Pojawienie się lotniskowca było pierwszą tego rodzaju operacją przeprowadzaną w czasie prezydentury Donalda Trumpa. Dowodzący grupą kontradmirał James Kilby określił jej zadania jako „zademonstrowanie silnych więzi z sojusznikami, partnerami i przyjaciółmi w regionie" ${ }^{10}$. Elementem osłabiającym znaczenie tych gestów (tak jak w przypadku podobnych operacji za prezydentury Obamy) był fakt, że żadne z zaprzyjaźnionych państw Azji Południowo-Wschodniej, wbrew różnym wcześniejszym zapowiedziom, nie dołączyło do wspomnianych operacji „wolności żeglugi” ani do patroli lotniczych.

Niepokojące mogły być także słowa głównego stratega ekipy Trumpa, Steve'a Bannona (którego pozycja polityczna uległa jednak później nieoczekiwanie osłabieniu), że widzi stosunki chińsko-amerykańskie jako konfrontacyjne

9 Viola Zhou, Trump on Asia: What He's Said and Where He Stands, „South China Morning Post", 10 listopada 2016.

${ }^{10}$ Liu Zhen, US Navy Carrier Group Begins South China Sea Patrols, „South China Morning Post", 19 lutego 2017. 
i przewiduje w okresie od pięciu do dziesięciu lat starcie obu potęg na Morzu Południowochińskim ${ }^{11}$.

\section{Reakcja Chin na pierwsze kroki nowej administracji USA dotyczące Morza Południowochińskiego i Azji Południowo-Wschodniej}

W odpowiedzi na deklaracje i działania amerykańskie strona chińska dała do zrozumienia, że jeszcze zwiększy obecność wojskową na Morzu Południowochińskim, jeżeli chodzi o instalacje na spornych wysepkach i rafach. Należy przypomnieć, że od 2009 r. Chiny oficjalnie, choć mało precyzyjnie (tak zwana linia dziewięciu kropek) ${ }^{12}$, zgłaszają pretensje do kontroli $80-90 \%$ powierzchni Morza Południowochińskiego. Zbieg okoliczności i zwiększona obecność wojskowa w regionie pozwoliły stronie chińskiej zademonstrować swoją gotowość do zdecydowanej reakcji. W połowie grudnia 2016 r. chiński okręt „Dalang III”, specjalizujący się we wsparciu dla okrętów podwodnych, przechwycił amerykańską sondę (dron) podwodną, należącą do amerykańskiego okrętu oceanograficznego USNS „Bowditch”, która badała warunki morskie na spornych akwenach. Według Amerykanów nastąpiło to na ich oczach około $90 \mathrm{~km}$ od brzegów Filipin na wysokości dawnej bazy morskiej USA Subic Bay ${ }^{13}$. Chińczycy zwrócili podwodny dron po kilku dniach, ale był to swego rodzaju sygnał ostrzegawczy, że wszystkie próby nawet niekonwencjonalnej ingerencji na spornych akwenach spotkają się ze zdecydowaną reakcją Pekinu. Potwierdziły to przeprowadzone pod koniec grudnia w regionie Morza Południowochińskiego manewry floty i sił powietrznych Chin. Natomiast wypowiedź Tillersona w czasie przesłuchania w senacie USA komentatorzy chińscy określili jako „nierealistyczną” i „nieodpowiedzialną”, wynikającą $\mathrm{z}$ całkowitego braku rozeznania w prawdziwej sytuacji w regionie ${ }^{14}$.

Strona chińska zwiększyła także wyraźnie ilość dostępnych informacji i opracowań eksperckich, przeznaczonych dla własnej, ale przede wszystkim dla zagranicznej opinii publicznej. Ujawniały one skalę amerykańskiego zaangażowania wojskowego w Azji Wschodniej, a w Azji Południowo-Wschodniej w szczególności (choć w miarę rozwoju sytuacji na Półwyspie Koreańskim coraz więcej uwagi poświęca się także instalacji rakiet i radarów THAAD w Korei Południowej i szerzej sytuacji w Azji Północno-Wschodniej). Chińscy eksperci zwracali przede wszystkim uwagę, że około 97 tys. żołnierzy USA stacjonuje w regionie na zachód od

${ }^{11}$ Deng Yuwen, In the Trump Era, We Can't Rule Out War Between China and the US, Whether Over Trade or Security, „South China Morning Post”, 10 lutego 2017.

${ }^{12}$ Linią 9 kropek (lub 9 kresek) określa się pas wyznaczający zakres chińskich roszczeń na Morzu Południowochińskim (przyp. red.).

13 „Le Monde” za AFP, 16 grudnia 2016.

${ }^{14}$ Hugh White, With Their Threats To China, Trump and Tillerson Are Making Rookie Blunders That Will Only Hurt US Credibility, ,South China Morning Post”, 17 stycznia 2017. 
międzynarodowej linii zmiany daty, a całe siły w regionie Azji i Pacyfiku to ponad 50\% wszystkich sił USA stacjonujących za granicą. W regionie USA używają na dużą skalę samolotów i dronów zwiadowczych, okrętów rozpoznania elektronicznego, atomowych okrętów podwodnych i satelitów obserwacyjnych, czym potwierdzają, że Chiny stały się celem numer jeden wszelkiego typu operacji wywiadowczych, zarówno pod względem zakresu, jak i częstotliwości oraz złożoności prowadzonych działań. Chińczycy zwrócili zwłaszcza uwagę na częstotliwość misji rozpoznawczych USA na Morzu Południowochińskim, a także na próby wciągnięcia krajów Azji Południowo-Wschodniej w operacje wymierzone przeciwko Chinom, w tym po raz pierwszy wspomnieli o takich krokach wobec Singapuru. Pokazuje to zdaniem Pekinu, że Morze Południowochińskie odgrywa kluczową rolę w amerykańskiej polityce pivot, a faktycznie w polityce powstrzymywania Chin ${ }^{15}$. Wpłynięcie eskadry z USS „Carl Vinson” na Morze Południowochińskie strona chińska odczytała jako przesłanie USA do świata, że nowa administracja stara się jednak podtrzymać strategię pivot Obamy, której końcowym celem jest powstrzymanie wzrostu roli Chin i zachowanie pozycji hegemona w Azji ${ }^{16}$.

Niezależnie od gestów polityczno-wojskowych (w tym zakończenie budowy pełnowartościowych lotnisk wojskowych na Wyspach Spratly, takich jak Subi, Fiery Cross i Mischief) strona chińska kontynuuje politykę rozwijania wszechstronnej obecności, w tym cywilnej, na spornych wyspach w regionie. W lutym 2017 r. agencja Xinhua poinformowała o otwarciu filii Commercial Bank of China w Sancha, małej osadzie na wyspie Yongxing na Wyspach Paracelskich. Na wyspie mieszkają 242 osoby i osada ma status powiatu prowincji Hajnan. Na wyspie jest także zakład odsalania wody morskiej i lotniczy pas startowy liczący $2,5 \mathrm{~km}$ oraz od niedawna również instalacje rakietowe. Osada jest rozwijana od $2012 \mathrm{r}$. Powyższy fakt pokazuje spokojne i konsekwentne normalizowanie i rozbudowę obecności Chin na spornych akwenach i terytoriach. Wywołało to krytyczną reakcję jedynie MSZ Wietnamu, konsekwentnie nieuznającego opanowania Wysp Paracelskich przez Chiny.

Bezpośrednio po oficjalnym wycofaniu się USA z TPP Chiny potwierdziły zainteresowanie kontynuowaniem prac nad integracją gospodarczą na obszarze Azji i Pacyfiku oraz wspomniały o RCEP i FTAAP. Chińscy komentatorzy jednoznacznie ocenili, że przed Chinami otwierają się nowe możliwości organizowania współpracy w regionie.

Sesja parlamentu w Pekinie (marzec 2017) była okazją do wypowiedzi na temat sytuacji na Morzu Południowochińskim rzeczniczki parlamentu Fu Ying,

${ }^{15}$ Report On The Growing US Military Presence in The Asia - Pacific Region, „China Daily”, 26 listopada 2016.

${ }^{16}$ Xu Lushan, US Resumes Its Provocative Action in Sea, „China Daily”, 22 lutego 2017. 
doświadczonej dyplomatki, wielokrotnej ambasador w ważnych dla Chin krajach, która oświadczyła, że przyszłość regionu będzie zależeć od postępowania Waszyngtonu, choć Pekin jest gotowy stawić czoło każdej sytuacji. Równocześnie Fu Ying zaprzeczyła, jakoby Pekin zamierzał rzucić wyzwanie międzynarodowemu porządkowi światowemu, któremu przewodzi Waszyngton, i jego roli supermocarstwa ${ }^{17}$. Fu Ying zwróciła też uwagę, że większość Amerykanów, w tym ich przywódcy, nadal nie rozumie Chin mimo rosnących kontaktów ludzkich i wymiany gospodarczej. Sesja parlamentu była również okazją przy dyskusji o budżecie obronnym, do przedstawienia planów dalszej rozbudowy sił morskich celem lepszego równoważenia sił morskich USA na morzach przylegających do Chin.

\section{Reakcja Japonii w Azji Południowo-Wschodniej}

Japonia kontynuowała aktywne działania w regionie Azji Południowo-Wschodniej, mające wyraźnie na celu z jednej strony umocnienie własnych wpływów $i$ interesów i wspieranie działań USA, z drugiej aktywne działania na rzecz hamowania i ograniczania wzrostu wpływów Chin.

Należy przede wszystkim odnotować wizytę Shinzō Abe na Filipinach w lutym 2017 r. (w styczniu złożył wizyty w Indonezji i Wietnamie, a także w Australii). Japoński premier wyraźnie starał się nawiązać dobry kontakt z kontrowersyjnym i zmiennym w nastrojach prezydentem Filipin Rodrigo Duterte, a równocześnie przedstawił rozbudowany pakiet działań pomocowych i rozwoju współpracy gospodarczej o łącznej sumie około 9 mld dolarów. Japońskie propozycje wyraźnie miały na celu odciągnięcie, a przynajmniej zmniejszenie zaangażowania gospodarzy we współpracę z Chinami, które również zaoferowały znaczne środki pomocowe i nowe projekty współpracy.

Japonia wyraziła także gotowość udziału w demonstracyjnych manewrach floty USA i kilku innych państw zachodnich na Morzu Południowochińskim, zaplanowanych pierwotnie na maj, a potem przełożonych na bliżej nieokreślony termin w 2017 r. W eskadrze japońskiej miałby się znaleźć jej największy okręt wojenny „Izumo”, który, oficjalnie określany jako helikopterowiec, może być w bardzo krótkim czasie przezbrojony na lotniskowiec. Japońska marynarka wojenna w lipcu 2016 r. już uczestniczyła w ćwiczeniach antypirackich z marynarką filipińską w Zatoce Manilskiej, co spotkało się ze zdecydowaną krytyką Chin. Zapowiada to eskalację napięć na Morzu Południowochińskim również z udziałem Japonii.

17 Shi Jiangtao, Future of South China Sea Disputes Depends on Washington, Says China's Legislature Spokeswomen, „South China Morning Post”, 4 marca 2017. 


\section{Państwa Azji Południowo-Wschodniej wobec rozwoju wydarzeń}

Filipiny

Wśród państw regionu reakcje na rozwój sytuacji były dość zróżnicowanie. Jednym z krajów najbardziej bezpośrednio dotkniętych zmianami były Filipiny. Kraj znalazł się w centrum sporu o Morze Południowochińskie, zwłaszcza od czasu, kiedy w 1994 r. pojawił się chiński garnizon wojskowy na rafie Mischief. Sytuacja zaostrzyła się jeszcze bardziej w roku 2012, kiedy okręty chińskie zaczęły odpędzać rybaków i filipińską straż przybrzeżną od rafy Scarborough. Po objęciu urzędu 30 czerwca 2016 r. nowy prezydent Filipin Rodrigo Duterte ograniczył współpracę wojskową z USA, wstrzymał zwłaszcza realizację wspólnych patroli morskich z Amerykanami na spornych wodach. Była to reakcja na bardzo negatywne oceny administracji Obamy dotyczące jego metod zwalczania handlarzy narkotyków oraz braku efektów współpracy z Amerykanami, zarówno wobec poczynań Chin, jak i w walce z islamistami na południu kraju. Duterte zaprzestał także powoływania się na korzystny dla Filipin wyrok Trybunału Arbitrażowego w Hadze z 12 czerwca 2016 r. i stara się wykorzystywać możliwości, które stwarzają propozycje chińskie złożone podczas jego wizyty w Pekinie w październiku 2016 r. Związki chińsko-filipińskie miała jeszcze umocnić czterodniowa wizyta wicepremiera Wang Yanga w połowie marca. W jej przededniu firmy chińskie zakontraktowały zakupy towarów filipińskich (między innymi banany, ananasy, olej kokosowy, drewno, miedź katalityczna i rudy niklu) na olbrzymią sumę ok. 1,7 mld dolarów. Duterte zaangażował się w inicjatywę OBOR i wziął udział w poświęconym jej forum w Pekinie w maju 2017 r.

W swojej niezależnej polityce filipiński prezydent posunął się nawet do zgody na pierwszą oficjalną wizytę dwóch rosyjskich okrętów wojennych w styczniu 2017 r., a następnie na kolejną innej eskadry rosyjskiej w kwietniu. Swoją politykę potwierdził wizytą w Moskwie na końcu maja 2017 r., kiedy wyraził zainteresowanie dostawami broni rosyjskiej ${ }^{18}$. Duterte zdaje sobie sprawę zarówno z istniejących sojuszy obronnych Filipin z USA (pierwszy z 1951 r.) i powiązań kierownictwa filipińskich sił zbrojnych z partnerami ze Stanów Zjednoczonych, jak i z bardzo silnej pozycji USA w gospodarce Filipin (drugi rynek eksportowy i drugie źródło importu, 40\% inwestycji zagranicznych w 2015 r. i dominacja firm amerykańskich $\mathrm{w}$ tak zwanych usługach business process outsourcing, bardzo ważnych dla gospodarki filipińskiej ${ }^{19}$ ). Ma też świadomość słabej międzynarodowej pozycji Filipin. Mimo to prowadzi trudną i niebezpieczną grę balansowania

${ }_{18}$ Isabelle Mandraud, Le président philippin demande des armes à son homologue russe Vladimir Poutine, „Le Monde”, 24 maja 2017.

${ }^{19}$ François Xavier Bonnet, Quand Manille manoeuvre, „Le Monde diplomatique”, maj 2017. 
pomiędzy wielkimi graczami w regionie i stara się wykorzystać ich rywalizację do przyśpieszenia rozwoju gospodarczego. Mogą na to wskazywać takie fakty jak wspomniana wizyta japońskiego premiera (sam Duterte był w Tokio w końcu października 2016 r.) oraz utrzymanie części współpracy wojskowej z USA, w tym zaplanowanych na 2017 r. corocznych wspólnych manewrów wojskowych, być może z udziałem jednostek japońskich.

Pewną nerwowość prezydenta Duterte może potwierdzać jego polecenie z pierwszych dni kwietnia 2017 r., aby siły zbrojne szybko zajęły te wysepki i rafy na Morzu Południowochińskim (dziewięć lub dziesięć), do których Manila zgłasza pretensje, a które nie są obsadzone przez siły innych krajów ${ }^{20}$. Z całą pewnością nie spodobała się ona Pekinowi. Najnowsze informacje potwierdzają, że Duterte stara się lawirować pomiędzy całkowicie sprzecznymi naciskami i oczekiwaniami Pekinu i Waszyngtonu. Sytuację prezydenta może jeszcze skomplikować dalsze wzmocnienie się grup radykalnych islamistów na południu kraju. Na konferencji Milipol w Singapurze, poświęconej sprawom bezpieczeństwa, pojawiły się oceny z wiarygodnych źródeł, że na południe Mindanao i na pobliskie mniejsze wyspy, mimo wysiłków rządu w Manili, będą przenikać bojownicy powracający z Bliskiego Wschodu ${ }^{21}$. Informacje te mogą potwierdzać zajadłe walki, które wybuchły w końcu maja w mieście Marawi na Mindanao między siłami rządowymi a islamskimi bojownikami z organizacji Abu Sayaaf i Maute. Umiejętności polityczne prezydenta zostają tym bardziej wystawione na próbę, ponieważ w $2017 \mathrm{r}$. Filipiny przejęły przewodnictwo w ASEAN.

\section{Wietnam}

Polityka Wietnamu znacznie różniła się od filipińskiej, na co złożyło się bardzo wiele czynników, w tym potencjał wojskowy, położenie geograficzne czy zaszłości historyczne. Po entuzjastycznym przyjęciu czterodniowej wizyty prezydenta Obamy w końcu maja 2016 r., w czasie której ogłosił on całkowite zniesienie embarga na sprzedaż broni do Wietnamu i uzgodnił dalszy rozwój współpracy, władze Wietnamu, w miarę rozwoju kampanii wyborczej w USA, utwierdziły się jednak szybko w słuszności swojej dotychczasowej ostrożnej i wielokierunkowej polityki zagranicznej. Jesienią 2016 r. było już wysoce prawdopodobne, że polityka Obamy w Azji Wschodniej albo zostanie w dużym stopniu zmodernizowana, albo nawet całkowicie odrzucona. Pierwszym skutkiem tej tendencji było porzucenie przez prezydenta Trumpa porozumienia TPP, do którego ratyfikacji Wietnam był

${ }^{20}$ Le président philippin ordonne l'occupation d'îlots disputés en mer de Chine, „Le Monde”, za: AFP 6 kwietnia 2017.

${ }^{21}$ Security Experts Warn that Southern Philippines May Become ,Sanctuary” for IS Fighters Returning From Middle East, ,South China Morning Post”, za: AFP, 4 kwietnia 2017. 
przygotowany i z którym wiązał duże nadzieje gospodarcze i polityczne (Wietnam, obok Australii i Meksyku, podejmuje próby ratowania TPP). Wietnamczycy, pomni korzystnego dla nich wówczas wiarołomstwa Amerykanów wobec Wietnamu Południowego, już wcześniej starali się w miarę możliwości rozszerzać kontakty z innymi ważnymi partnerami, przede wszystkim z Japonią. Okazją do tego był wyjazd premiera Nguyen Xuan Phuca do Japonii, gdzie przebywał jako zaproszony gość na szczycie G7. Wyjazd miał miejsce bezpośrednio po wizycie Obamy i był pierwszą wizytą zagraniczną premiera po objęciu stanowiska po XII Zjeździe KPW. Zaproszenie wietnamskiego premiera potwierdza także dalekowzroczność polityki japońskiej i jej aktywizację w roku 2016. Japońska wizyta premiera Wietnamu zapoczątkowała wyjątkowe ożywienie relacji wietnamsko-japońskich. Premier Shinzō Abe, podczas „objazdu” państw regionu, złożył w styczniu 2017 r. wizytę w Wietnamie, na której uzgodniono wiele projektów inwestycyjnych, w tym w sektorze energetycznym i tekstylnym (Japonia jest drugim bezpośrednim inwestorem w Wietnamie po Korei Południowej oraz zajmuje trzecią pozycję w imporcie i eksporcie wietnamskim), a także realizuje obszerny program pomocowy. Abe zapowiedział również przekazanie nieodpłatnie sześciu nowych okrętów patrolowych o wartości łącznej ponad 1 mld dolarów (już wcześniej Japonia przekazała sześć używanych patrolowców), co było wyraźnym gestem przeciwko zagrożeniu ze strony Chin. Doskonały stan stosunków dwustronnych potwierdziła nieco później wizyta japońskiej pary cesarskiej w Wietnamie.

Strona wietnamska starała się podejmować kontakty i współpracę również z innymi liczącymi się krajami spoza regionu. Potwierdziła to między innymi wizyta prezydenta Francji oraz rozbudowa współpracy, w tym wojskowej, z Indiami, Rosją i Australią.

Kluczowe znacznie miały i mają jednak stosunki z Chinami. Polityka Hanoi na tym kierunku była konsekwentna i aktywna. Premier Nguyen Xuan Phuc złożył wizytę w Chinach we wrześniu $2016 \mathrm{r}$. W ramach tej polityki odbyła się również wizyta sekretarza generalnego KPW Nguyen Phu Truonga w połowie stycznia 2017 r. Potwierdziła ona dążenie do podtrzymywania wszechstronnych i wielopoziomowych kanałów dialogu z Chinami, obejmujących wszystkie ośrodki władzy w obu krajach, z silnym akcentem na kontakty partyjne, które niekiedy ułatwiały rozwiązywanie spraw trudnych. Takim kanałem jest między innymi Wietnamsko-Chiński Komitet Sterujący do spraw Współpracy Dwustronnej, w ramach którego dochodzi do kontaktów wysokiego szczebla, jak ostatnio w kwietniu $2017 \mathrm{r}$. do rozmów w Pekinie ministrów spraw zagranicznych Pham Binh Minha i Wang Yi. Zaangażowanie Wietnamu w skomplikowany i trudny dialog z Chinami potwierdziła oficjalna wizyta prezydenta Tran Dai Quanga w Chinach w maju 2017 r. i jego udział $w$ forum poświęconym inicjatywie Pasa i Szlaku (OBOR). Między 
oboma krajami funkcjonują też specjalne linie łączności ministrów obrony i służb resortów spraw wewnętrznych, dość regularnie prowadzone są rozmowy dotyczące demarkacji ujścia Zatoki Tonkińskiej na Morze Południowochińskie (w samej zatoce demarkacja została uzgodniona w roku 2000).

Dla Wietnamu wielkim wyzwaniem jest stały wzrost gospodarczych wpływów potężnego północnego sąsiada. Mimo ostrożnej polityki władz wietnamskich Chiny stale zwiększają swój udział w bezpośrednich inwestycjach zagranicznych. Kilka lat temu zajmowały ósme miejsce wśród zagranicznych inwestorów, ale w $2016 \mathrm{r}$. już drugie, ustępując tylko Singapurowi, a będąc przed Koreą Południową (inwestycje chińskie przekroczyły 11 mld dolarów). W wymianie handlowej (obroty dwustronne w 2016 r. to około 72 mld dolarów) Chiny są drugim rynkiem eksportowym dla Wietnamu (po USA) i pierwszym źródłem importu, przed Koreą Południową i Japonią 22. Problemem jest zwłaszcza wysokie ujemne saldo wymiany niekorzystne dla Wietnamu i co roku wynoszące ponad 10 mld dolarów.

Kierownictwo wietnamskie z jednej strony stara się prowadzić intensywny dialog i wiązać wszechstronną współpracą chińskiego partnera, z drugiej aktywnie poszukiwać wszystkich możliwych silnych partnerów, z którymi współpraca może przynajmniej częściowo ograniczać znaczenie stosunków i presję ze strony Chin. Początkowe milczenie prezydenta Trumpa w sprawie relacji z Wietnamem i brak jasności co do jego polityki wobec Chin mogły tylko niepokoić władze w Hanoi. Tym bardziej że co jakiś czas dochodzi do wzrostu napięcia z Chinami na tle sporu na Morzu Południowochińskim. Przykładowo strona chińska w październiku i listopadzie 2016 r. ostro krytykowała Wietnam za umacnianie i rozbudowę swoich pozycji na niektórych wysepkach archipelagu Spratly ${ }^{23}$. Tymczasem to właśnie Chiny, szczególnie od ostatnich trzech lat, prowadzą takie prace na dużą skalę na wysepkach i rafach na spornych obszarach Morza Południowochińskiego. Natomiast Wietnam jest niewątpliwie drugim po Chinach krajem w regionie, jeżeli chodzi o liczbę obsadzonych wojskiem wysp i raf Spratly. Czemu zresztą nie należy się dziwić po bardzo bolesnych doświadczeniach starcia w regionie z Chinami w 1988 r. oraz licznych incydentach, w których siły chińskie działały wobec Wietnamczyków bardzo bezwzględnie, wykorzystując swoją przewagę, tak jak podczas pracy chińskiej platformy wiertniczej nr 981 w pobliżu Wysp Paracelskich w 2014 r. Z tym większą ulgą wietnamskie kierownictwo przyjęło realizację w kwietniu 2017 r. wizyty w USA swojego ministra spraw zagranicznych (i wicepremiera) Pham Binh Minha i rozmowy z Rexem Tillersonem oraz z doradcą w Narodowej Radzie Bezpieczeństwa

22 Pocket World in Figures, „The Economist” 2017.

${ }^{23}$ China Urges Vietnam To Stop Construction on South China Sea Island, „China Daily”, za: Xinhua, 18 listopada 2016; Mo Jingxi, Vietnam Dredging on Chinese Reef It Occupies, „China Daily”, 11-12 października 2016. 
Herbertem Raymondem McMasterem. Odbyły się też rozmowy z sekretarzem skarbu Stevenem Mnuchinem. Strona wietnamska między innymi przekazała zaproszenie dla Donalda Trumpa na szczyt APEC w 2017 r. i do odwiedzenia oficjalnie Wietnamu. Omówiono także sytuację na Morzu Południowochińskim. Amerykanie obiecali poparcie w sprawie pomocy Banku Światowego dla Wietnamu. Ponowne ożywienie kontaktów wietnamsko-amerykańskich potwierdziła wizyta wietnamskiego premiera Nguyen Xuan Phuca w USA i przyjęcie go przez Donalda Trumpa w końcu maja. Strony podkreśliły też znaczenie swobody żeglugi i przelotów na Morzu Południowochińskim oraz pokojowego rozwiązywania sporów zgodnie $\mathrm{z}$ międzynarodowym prawem. Trump potwierdził wizytę w Wietnamie w listopadzie z okazji szczytu APEC. W ramach dalszej ofensywy dyplomatycznej premier Wietnamu udał się po wizycie w USA do Japonii.

\section{Malezja}

Krajem regionu, który również w ostatnim okresie dokonał zmiany w polityce zagranicznej w nawiązaniu do rodzącego się nowego układu sił w regionie, była Malezja. Pod długimi rządami premiera Mahathira Mohamada (1981-2003) kraj był od wielu lat skonfliktowany z państwami zachodnimi, chociaż istniały formalne związki w postaci Porozumienia Obronnego Pięciu Potęg (Five Power Defence Arrangements) z 1971 r. obejmującego Malezję, Singapur, Wielką Brytanię, Australię i Nową Zelandię. Po ustąpieniu Mahathira, mimo początkowych bardzo powolnych postępów, po objęciu funkcji premiera przez Najiba Tun Razaka w $2009 \mathrm{r}$. wydawało się, że proces naprawy relacji będzie szybki i bezproblemowy. Rzeczywiście stosunki z Zachodem, w tym z USA, poprawiły się. W 2014 r. wizytę w Malezji złożył prezydent Obama, a w 2015 premier Wielkiej Brytanii David Cameron (zresztą w tym roku prezydent Obama po raz drugi odwiedził Malezję w związku z serią konferencji międzynarodowych).

Malezja wkrótce powróciła jednak jako obiekt krytyki w 2015 r., początkowo głównie mediów zachodnich i organizacji praw człowieka, z powodu, zapewne motywowanego politycznie, wyroku sądowego wydanego na jednego z przywódców opozycji Anwara Ibrahima, od wielu lat popieranego przez różne siły z krajów zachodnich. Równocześnie rząd i sam premier Najib zostali poddani ostremu atakowi opozycji w związku z nieprawidłowościami w zarządzaniu funduszem suwerennym 1 Malaysia Development Berhad (1 MDB), gdzie nadużycia miały sięgać 1 mld dolarów. Sprawa stała się przedmiotem śledztw również w Szwajcarii, USA, Luksemburgu i Singapurze ${ }^{24}$. Spowodowało to także stopniowo kolejne ochłodzenie stosunków z państwami zachodnimi, które, niezależnie od ostrych

${ }^{24}$ Amy Chew, Mahathir Takes Swipe at Najib Over Malaysia's Stupid'Chinese Business Deal, „South China Morning Post”, 27 czerwca 2016. 
oskarżeń w mediach, pośrednio dawały do zrozumienia, że oczekują dymisji Najiba. Premier, atakowany zarówno wewnątrz kraju, jak i z zewnątrz, w poszukiwaniu możliwości wzmocnienia swojej pozycji postawił na współpracę z Pekinem i na przełomie października i listopada 2016 r. złożył oficjalną wizytę w Chinach. Podpisano wówczas wiele kontraktów handlowych i projektów inwestycyjnych, obejmujących między innymi budowę linii kolejowych i gazociągu w prowincji Sabah. Uzgodnienia podczas wizyty były bardzo szerokie - od projektów inwestycji infrastrukturalnych do współpracy w dziedzinie edukacji i nauki. Strona chińska zobowiązała się do włączenia Malezji w główny nurt inicjatywy OBOR. Największym zaskoczeniem był jednak kontrakt na cztery okręty patrolowe dla Malezji oraz uzgodnienie dalszej współpracy w zakresie budowy okrętów wojennych. Dotychczas Malezja, niezależnie od stanu stosunków, zaopatrywała się w sprzęt wojskowy w krajach zachodnich ${ }^{25}$. Wyniki wizyty Najiba uznano za dodatkowy cios zadany polityce pivot prezydenta Obamy i mogą oznaczać ewolucję polityki zagranicznej Malezji w kierunku zbliżenia z Chinami. Mimo ostrej krytyki opozycji, a nawet z szeregów własnej partii (między innymi Mahathir), zarzucającej wyprzedawanie suwerenności (takie zarzuty pojawiły się już wcześniej w połowie 2016 r., kiedy pozwolono na przejęcie przez firmę chińską jednej z dużych firm malezyjskich sektora energetycznego) i znaczne osłabienie pozycji kraju w sporze o obszary na Morzu Południowochińskim, premier Najib konsekwentnie realizuje uzgodnienia. Ponadto zacieśnił współdziałanie z drugim przywódcą w regionie, który próbuje rozgrywać kartę chińską - z prezydentem Filipin Dutertem.

Trudno przewidzieć dalszy rozwój polityki zagranicznej Malezji, ale zacieśnienie relacji z Chinami jest już faktem i proces ten najprawdopodobniej będzie się pogłębiał. W 2015 r. obroty handlowe między oboma krajami wyniosły około 55,7 mld dolarów i dynamicznie rosną, Chiny są dla Malezji drugim rynkiem dla eksportu po Japonii i pierwszym źródłem importu przed Singapurem ${ }^{26}$. Koncepcja budowy przez firmy chińskie i malezyjskie nowego wielkiego portu kontenerowego w pobliżu historycznego portu Malakka, w ramach realizacji idei „Morskiego Jedwabnego Szlaku XXI wieku”, potwierdza umacnianie się powiązań gospodarczych obu krajów. Natomiast udział chińskich sił specjalnych w manewrach malezyjskich Selangor w listopadzie 2016 r. potwierdza otwarcie na wszechstronną współpracę, w tym wojskową, z Chinami. Stąd jego obecność na Forum OBOR w Pekinie w maju 2017 r. Dla znajdującego się w trudnej politycznie sytuacji Najiba dynamiczny rozwój współpracy z Chinami może być szansą na przezwyciężenie trudności nie tylko gospodarczych, ale i politycznych. Kalendarz wydarzeń

${ }^{25}$ Brice Pedroletti, Bruno Philip, Le premier ministre malaisien joue la carte chinoise, „Le Monde”, 2 listopada 2016.

${ }^{26}$ Pocket World... 
politycznych świata zachodniego, w tym szczególnie wybory prezydenckie w USA, stworzyły dla niego taką szansę.

Jeżeli chodzi o inne państwa regionu, to rola niektórych jest ograniczona i stosunkowo łatwa do przewidzenia, w przypadku innych może być istotna, ale trudno określić kierunek ich działań w przyszłości.

\section{Kambodża}

W przypadku Kambodży sytuacja jest klarowna przynajmniej w krótkiej, a nawet średniookresowej perspektywie. Chiny są bardzo ważnym partnerem handlowym, głównym dawcą pomocy rozwojowej i inwestorem. Przekazują także pokaźną, kluczową wręcz pomoc dla kambodżańskich sił zbrojnych. Wpływy chińskie są także decydujące, jeżeli chodzi o politykę zagraniczną, czego wyrazem było rozbicie przez Kambodżę jedności państw ASEAN na szczycie ASEAN-Chiny w czerwcu 2016 r. (Było to powtórzenie tego, co się wydarzyło na spotkaniu ministrów spraw zagranicznych ASEAN w Phnom Penh w lipcu 2012 r., kiedy Kambodża zablokowała w interesie Chin przyjęcie komunikatu końcowego spotkania). Od tego czasu polityka kambodżańska tylko umocniła kurs całkowitego podporządkowania się woli Pekinu.

Rządzący krajem od ponad 30 lat premier Hun Sen (objął to stanowisko w 1985 r.) nie ma żadnego interesu, by zmieniać swoje prochińskie stanowisko, które znacznie umacnia jego pozycję w kraju i za granicą. Wybory do władz lokalnych w czerwcu 2017 r., a następnie do senatu zaplanowane na styczeń 2018 r. i do Zgromadzenia Narodowego w lipcu 2018 r. będą w nadchodzących miesiącach w centrum uwagi Hun Sena, który prawdopodobnie i tym razem utrzyma władzę. Działania podejmowane przez Hun Sena wobec byłego szefa opozycji Sama Rainsy - przebywającego zresztą na emigracji - to znaczy kolejne skazanie za zniesławienie, nie zapowiadają niczego dobrego dla opozycji. Tylko inny wynik wyborów w 2018 r., w tych warunkach i tak bardzo mało prawdopodobny, mógłby stworzyć warunki do ewolucji polityki zagranicznej Phnom Penh.

\section{Laos}

Po zmianach wywołanych X zjazdem rządzącej jedynej partii LRPL Laos koncentruje się na utrzymaniu wysokiego tempa wzrostu gospodarczego - ponad 7\% rocznie. W stosunkach zagranicznych prowadzona jest polityka równoważenia relacji z Chinami i Wietnamem. Chiny, największy inwestor i główny partner handlowy, zajmują dominującą pozycję w gospodarce. Mimo to utrzymuje się silna pozycja tradycyjnego partnera - Wietnamu, również mocno obecnego w gospodarce: jest drugim inwestorem po Chinach i ma przeważające wpływy w siłach zbrojnych. Niektórzy obserwatorzy oceniają, że po X zjeździe LRPL nowa ekipa 
kierownicza podjęła ostrożne działania na rzecz ponownego zrównoważenia rosnącej od kilku lat dominacji chińskiej obecnością wietnamską ${ }^{27}$. Mimo tych sygnałów Laos nie może sobie pozwolić w polityce zagranicznej na jakiekolwiek większe odstępstwa od linii „sugerowanej” przez Chiny, a w przypadku wzrostu napięć na linii Pekin-Hanoi będzie się starał trzymać ścisłej neutralności.

Zabiegi o pewien wzrost wpływów w tym kraju ze strony USA, Indii, a nawet Rosji nie mają na razie większego znaczenia.

\section{Brunei}

Sułtanat Brunei, mimo bardzo konserwatywnej polityki wewnętrznej - od $2013 \mathrm{r}$. obowiązuje tam prawo szarijatu - w polityce zagranicznej i w relacjach gospodarczych z zagranicą jest nastawiony na rozwój relacji z Chinami. Chiny importują dużo ropy, która stanowi ponad $90 \%$ eksportu sułtanatu. Pekin jest też dostawcą dużych ilości towarów, w tym żywności halal, na rynek Brunei. Dobre relacje istnieją niezależnie od różnic co do podziału obszarów na Morzu Południowochińskim, gdzie pretensje Brunei dotyczą niewielkich obszarów i opierają się na argumentach historycznych oraz na międzynarodowych konwencjach w sprawie wód terytorialnych ${ }^{28}$. Z racji ograniczonego potencjału Brunei nie jest na pierwszej linii konfliktu o podział stref na spornym akwenie. Ponadto wydaje się, że Chiny dysponują odpowiednimi instrumentami, aby w razie potrzeby przynajmniej zneutralizować stanowisko sułtanatu, chociażby poprzez wzrost ilości i ceny zakupów surowców energetycznych.

\section{Tajlandia}

Tajlandia pozostaje od kliku lat całkowicie zaabsorbowana problemami wewnętrznymi, które wynikają z głębokiego konfliktu obejmującego zarówno elity, jak i szerokie masy społeczeństwa. Konsekwencją tego konfliktu był wojskowy zamach stanu w maju 2014 r. i sprawowanie władzy przez wojsko do dnia dzisiejszego. Na tę trudną sytuację nałożyła się śmierć króla Ramy IX (Bhumibola Adulydeja) w październiku 2016 r., co postawiło przed władzami problem zarówno organizacji ceremonii pogrzebowych wielce szanowanego monarchy, jak i intronizacji jego następcy, proklamowanego królem 1 grudnia 2016 r., bardzo kontrowersyjnego księcia Vajiralongkorna (Ramy X). Pierwsze miesiące panowania nowego króla pokazują, że współpraca monarchy z rządem generała Prayuth'a Chan-ocha nie będzie bezproblemowa. Król zgłosił już kilka uwag merytorycznych do projektu nowej konstytucji, czym mocno skomplikował planowany kalendarz polityczny

${ }_{27}$ Bruno Philip, Le Laos, pays enclave et regime repressive, „Le Monde”, 8 września 2016.

${ }^{28}$ Morze Poludniowochińskie: serce potencjalnego konfliktu w Azji, Centrum Stosunków Międzynarodowych, Warszawa, maj 2016, s. 9, 23. 
procesu powrotu do stanu normalności, jaki przygotowywali wojskowi, starający się w sposób zakamuflowany zachować dla siebie decydujące wpływy w kraju.

W relacjach z zagranicą Tajlandia z jednej strony stara się przywrócić normalność relacji z tradycyjnym sojusznikiem USA (współpraca datuje się na okres bezpośrednio po II wojnie światowej, a formalny sojusz z 1962 r.; w 2003 za udział tajskich kontyngentów medycznych i inżynieryjnych w operacjach w Afganistanie i Iraku, u boku wojsk USA, przyznano Tajlandii status „ważnego sojusznika spoza NATO”) i pewnym sukcesem był powrót do wspólnych ćwiczeń wojskowych „Cobra Gold”, a także z Japonią, która ma w kraju bardzo silną pozycję gospodarczą. Z drugiej prowadzi politykę rozwijania relacji z Chinami, zwłaszcza gospodarczych, i stara się korzystać z ofert inwestycyjnych Pekinu, szczególnie w rozbudowie sieci kolejowej w ramach wielkiego projektu Trans Asia Railway, oraz z rosnącego napływu turystów chińskich. Zupełnie nowym wydarzeniem w relacjach z Pekinem było zakontraktowanie budowy przez Chiny okrętu podwodnego. Wprawdzie Tajlandia kupowała już broń i sprzęt wojskowy w Chinach, ale nigdy nie dotyczyło to sprzętu o tak strategicznym znaczeniu. Stosunki gospodarcze Tajlandii z zagranicą są jednak nadal dość zrównoważone - Chiny są pierwszym rynkiem dla eksportu tajskiego przed USA i Japonią oraz drugim źródłem importu po Japonii, a przed USA ${ }^{29}$. Zależności od Chin ciągle jeszcze ustępują połączonym wpływom USA i Japonii.

Wysokiej rangi dyplomata tajski zapytany o stanowisko Tajlandii w zarysowującym się nowym układzie sił $\mathrm{w}$ regionie odpowiedział bez wahania: $\mathrm{w}$ sytuacji konfliktowej staniemy , jak zwykle" po stronie silniejszego ${ }^{30}$.

\section{Mjanma/Birma}

Położona na krańcu Azji Południowo-Wschodniej Mjanma/Birma jest na razie nieco mniej włączona w nową rozgrywkę o wpływy w regionie. Należy jednak pamiętać o jej strategicznym położeniu pomiędzy krajami Półwyspu Indyjskiego a Chinami, jak również o tym, że właśnie sytuacja w tym kraju była wskazywana jako przykład sukcesu amerykańskiej polityki pivot. Choć faktycznie ten sukces byłby niemożliwy bez decyzji wojskowych rządzących do niedawna w Birmie, a teraz nadal w dużym stopniu kontrolujących sytuację.

Obecnie ukształtuje się w tym kraju krucha równowaga pomiędzy dużym wpływem chińskim, zwłaszcza w sektorach gospodarczych (w ostatnich latach został nieco ograniczony), a wpływami USA i Japonii, które znacznie wzrosły. Stopniowo rosną także wpływy Indii.

\footnotetext{
${ }^{29}$ Pocket World...

${ }^{30}$ Podczas rozmowy z autorem w styczniu $2017 \mathrm{r}$.
} 
Kierująca w praktyce krajem od kwietnia 2016 r. przewodnicząca Narodowej Ligi na rzecz Demokracji (NLD) pani Aung San Suu Kyi jest konfrontowana $\mathrm{z}$ kilkoma niezwykle trudnymi wyzwaniami, takimi jak utrzymanie szybkiego wzrostu gospodarczego tego zacofanego kraju, doprowadzenie do trwałego pokoju wewnętrznego z mniejszościami, a także kontynuowanie demokratyzacji przy utrzymywaniu dobrej współpracy z siłami zbrojnymi. Noblistka, dotychczas entuzjastycznie traktowana przez zachodnie media, stała się nieoczekiwanie obiektem surowej, często nieuzasadnionej krytyki na tle sytuacji mniejszości Rohingya zamieszkującej w prowincji Arakan (Rakhine) na pograniczu z Bangladeszem. Rohingya, lud wyznania muzułmańskiego, to jedna z negatywnych spuścizn brytyjskiego kolonializmu, bo większość z nich napłynęła do Birmy jeszcze w czasach kolonialnych. Władze traktują ich jako uciekinierów z Bangladeszu, bez praw obywatelskich w Birmie. Sytuacja skomplikowała się, kiedy samozwańczy kalif państwa islamskiego Abu Bakr al-Baghdadi wyraził dla nich poparcie, a w październiku 2016 r. bliżej niezidentyfikowana grupa zbrojna o nazwie Yakin, rzekomo złożona z Rohingya, zaatakowała posterunek birmańskiej straży granicznej, co z kolei spowodowało ostre represje ze strony wojska birmańskiego.

Należy się obawiać, że bojownicy Państwa Islamskiego, coraz liczniej obecni i aktywni w graniczącym z Birmą Bangladeszu (zamach w Dakce w lipcu 2016 r.), będą chcieli przenieść wojnę z „niewiernymi” do Birmy, wykorzystując trudną sytuację i niezadowolenie Rohingya, związane z brutalnym działaniem wojska birmańskiego i aktywizujących się ekstremistów buddyjskich. Nie można też wykluczyć, że sytuację tę wykorzystają wielkie mocarstwa do rozgrywki o wpływy w Birmie, tak jak ma to miejsce na Bliskim Wschodzie.

\section{Singapur}

Singapur, który nie zgłaszał pretensji do spornych obszarów Morza Południowochińskiego i który jest koordynatorem relacji ASEAN z Chinami, dość nieoczekiwanie został wciągnięty w napięcia pomiędzy wielkimi mocarstwami od połowy 2016 r. Sprawa powstała po wypowiedzi singapurskiego premiera Lee Hsien Loonga podczas wizyty w USA w lipcu 2016 r., że jego kraj jest zadowolony z zaangażowania USA w regionie. Ponadto na terenie Singapuru od dawna znajdują się punkty oparcia dla floty i lotnictwa USA, operujących w regionie, a ich infrastruktura jest obecnie rozbudowywana. Miesiąc po wypowiedzi premiera, na spotkaniu wiceministrów spraw zagranicznych Chin i państw ASEAN, przedstawiciel Pekinu żądał, aby Singapur trzymał się z daleka od sporu o akweny morskie ${ }^{31}$. Od tego momentu zaczęły się mnożyć przejawy niezadowolenia Chin, które wzrosły

${ }^{31}$ Catherine Wong, Chinese Diplomat Tells Singapore to Stay out of South China Sea Disputes, „South China Morning Post”, 16 sierpnia 2016. 
w listopadzie 2016 r., kiedy omyłkowo na terenie portu w Hongkongu wyładowano dziewięć transporterów armii singapurskiej, powracających z ćwiczeń na Tajwanie. Praktyka taka była doskonale znana w Pekinie, ale pojawienie się bezpośrednich dowodów musiało zaostrzyć jego ton. Powstała sytuacja stanowi poważne wyzwanie dla władz Singapuru, który od czasu uzyskania niepodległości jeszcze pod kierownictwem Lee Kuan Yew z jednej strony zawsze stawiał na intensywny rozwój relacji z Chinami (w 2015 r. pierwszy odbiorca eksportu i pierwsze źródło importu), z drugiej zdecydowanie opowiadał się za utrzymaniem w regionie obecności Zachodu, a szczególnie silnej wojskowej obecności USA. Należy oczekiwać, że w swoim własnym interesie, ale i w interesie innych państw ASEAN Singapur będzie starał się aktywnie rozwiązywać napięcia $\mathrm{w}$ regionie poprzez dialog z głównymi mocarstwami, w tym z Chinami, co już próbuje realizować poprzez kontakty wysokiego szczebla. Pozwala mu na to jego mocna pozycja polityczna i gospodarcza w regionie oraz powszechny szacunek na świecie. W razie ewentualnej eskalacji napięć w regionie prawdopodobnie zdecydowanie opowie się po stronie ,prawa międzynarodowego gwarantującego prawo swobodnego przepływu i przelotu" nad Morzem Południowochińskim. Czyli w praktyce po stronie USA, Japonii i ich sojuszników.

\section{Indonezja}

Krajem o szczególnie złożonych relacjach z Chinami jest największy obszarem, gospodarką i liczbą ludności członek ASEAN - Indonezja. Na stosunki te nadal rzutują zaszłości związane z udziałem Chin w próbie przewrotu w 1965 r., brak stosunków dyplomatycznych w latach 1967-1990, a następnie przeszło piętnastoletni trudny okres przywracania normalnej współpracy. W 2015 r. prezydenci obu krajów, Xi Jinping i Joko Widodo, podpisali w Pekinie dokument o umocnieniu wszechstronnego strategicznego partnerstwa, co było ukoronowaniem znacznego ożywienia relacji w ostatnich kilku latach. Chiny stały się drugim rynkiem eksportowym dla Indonezji (po Japonii) i pierwszym źródłem importu (przed Singapurem i Japonią). Obroty handlowe z Chinami przekraczają 50 mld dolarów. Prezydent Widodo, który stara się przyśpieszyć rozwój gospodarczy kraju, liczy na napływ inwestycji chińskich, a przede wszystkim na włączenie kraju do głównego nurtu „Morskiego Jedwabnego Szlaku XXI wieku” i otwarcie możliwości korzystania z Funduszu Jedwabnego Szlaku oraz Banku Inwestycji Infrastrukturalnych (AIIB). Pierwsze doświadczenia z dużymi chińskimi inwestycjami nie były jednak najlepsze. Zarówno przy budowie elektrowni węglowej na Bali, jak i zwłaszcza linii szybkiej kolei Dżakarta-Bandung, pojawiały się nieprawidłowości, które doprowadziły między innymi do czasowego wstrzymania budowy linii kolejowej, wznowionej obecnie po około rocznej przerwie. Drugim problemem są 
sprawy Morza Południowochińskiego. Indonezja tradycyjnie starała się pozostać poza sporem w tej sprawie, ale jej apel, aby zainteresowane państwa zachowały umiar i nie eskalowały napięcia oraz wstrzymały się od działalności wojskowej, wydany po wyroku Sądu Arbitrażowego w Hadze, został źle przyjęty w Pekinie. Do tego doszło kolejne już przechwycenie przez jednostkę marynarki indonezyjskiej w czerwcu 2016 r. chińskich statków rybackich w pobliżu Archipelagu Natuna, co spowodowało protesty Pekinu. Chiny co prawda nie roszczą sobie pretensji do samych wysp, ale ich aspiracje do obszarów morskich w pobliżu (w ramach linii dziewięciu kropek) nakładają się na indonezyjską wyłączną strefę ekonomiczną. Mimo wspomnianych napięć prezydent Widodo podtrzymał zainteresowanie inwestycjami chińskimi ${ }^{32}$. Pozycję negocjacyjną Indonezji wzmacnia rywalizacja japońsko-chińska, która w ostatnich miesiącach nabrała rozmachu. W ramach objazdu państw regionu Dżakartę odwiedził w połowie stycznia 2017 r. Shinzō Abe (po wizytach w Australii i na Filipinach, a przed wizytą w Wietnamie). Japoński premier zachęcał Widodo do współpracy w zakresie bezpieczeństwa morskiego i wyraził gotowość do udziału w rozwoju Indonezji. Na miesiąc przed wizytą oba kraje zawarły porozumienie, które ma służyć umocnieniu zdolności Indonezji do obrony jej obszarów morskich. W czasie wizyty zatwierdzono kilka dużych projektów inwestycyjnych (inwestycje japońskie prawie się podwoiły w 2016 r. w porównaniu z 2015 r.), a prezydent Widodo zachęcał japońskie firmy do większej ofensywności, szczególnie w projektach kolejowych, gdzie początkowo spotkało je niepowodzenie w rywalizacji z konkurentami chińskimi.

Warto odnotować, że strony uzgodniły wspólne rozmowy ministrów obrony i spraw zagranicznych w roku 2017 na temat pogłębienia współpracy w dziedzinie obrony i bezpieczeństwa ${ }^{33}$. Indonezja, bardzo czuła na punkcie niezależności i swoich relacji z wielkimi mocarstwami, wobec czasowej ,nieobecności” USA w związku z wyborami i ze zmianą administracji, wyraźnie postawiła na relacje z Japonią i możliwość korzystania z rywalizacji obu mocarstw azjatyckich.

Dobre perspektywy rozwoju i wzmocnienia pozycji międzynarodowej Indonezji ograniczają sygnały o pewnym dalszym wzroście aktywności sił wewnętrznych, które nie wahają się posługiwać ludźmi i organizacjami powiązanymi z dawnymi siłami islamskiego terroryzmu (przykładem jest kampania wyborcza na gubernatora Dżakarty i w końcu porażka faworyta, protestanta i Chińczyka z pochodzenia, a nawet skazanie go przez sąd na dwa lata więzienia pod fałszywym zarzutem bluźnierstwa wobec islamu). Towarzyszy temu dalsza ogólna radykalizacja

32 Catherine Wong, Indonesian Leader Widodo's Emphasis on Development Boosts China Ties, „South China Morning Post”, 26 sierpnia 2016.

33 Indonesia, Japan To Deepen Defence Ties Amid China Challenge, „South China Morning Post", 15 stycznia 2017, AFP. 
środowisk islamskich. Wizyta króla Arabii Saudyjskiej wiosną 2017 i zapewne w związku z nią przeznaczenie przez Rijad dalszych olbrzymich środków na promowanie radykalnego wahabickiego islamu mogą również zachwiać obecną równowagę polityczną i społeczną. Także inne kraje Zatoki, a zwłaszcza Katar, kierują do Indonezji znaczne środki finansowe obliczone na upodabnianie indonezyjskiego tolerancyjnego islamu do jego fundamentalistycznych wersji z Bliskiego Wschodu. Największym jednak zagrożeniem byłoby, gdyby w ramach rosnącej rywalizacji wielkich mocarstw doszło do sprowokowania na dużą skalę zajść, na tle różnic religijnych i etnicznych, wymierzonych szczególnie w mniejszość chińską, które zmuszałyby Chiny do ostrych reakcji.

Wizyta wiceprezydenta USA Mike'a Pence'a w końcu kwietnia 2017 r. potwierdziła wyraźnie, że Waszyngton przywiązuje nadal wielką wagę do relacji z Dżakartą, z którą zresztą podpisał porozumienie o partnerstwie strategicznym w $2014 \mathrm{r}$.

\section{Wnioski}

1. Niezależnie od zmiany prezydenta i administracji Stany Zjednoczone mają stałe i niezwykle ważne interesy w regionie Azji i Pacyfiku. Są przekonane o stopniowo umacniającej się we współczesnym świecie roli Azji Wschodniej, w której żyje połowa ludności świata i, jeżeli doliczyć do regionu Indie, która w połowie XXI w. wytwarzała około 50\% światowej produkcji. W regionie tym już wielką i w miarę upływu czasu coraz większą rolę odgrywać będą Chiny. W ocenie niektórych ekspertów amerykańskich dążą one w sposób zakamuflowany do zmiany regionalnego i światowego status quo ${ }^{34}$. Spowodowało to sformułowanie w 2011 r. koncepcji pivot, czyli ponownego wzmocnienia obecności i oddziaływania USA w regionie, w tym także, chociaż nie mówi się o tym otwarcie, poprzez powstrzymanie i ograniczenie wpływów Chin. Odejście prezydenta Trumpa od porozumienia TPP pozbawiło czasowo plany amerykańskie w Azji komponentu ekonomicznego, znacznie je osłabiając. Mając jednak na uwadze wspomniane kluczowe znacznie regionu dla USA, należy oczekiwać, że wkrótce amerykańskie plany umacniania obecności w Azji i Pacyfiku zostaną zmodyfikowane i uzupełnione o nowe koncepcje gospodarcze wypełniające miejsce po TPP. Spotkanie prezydentów USA i Chin w Mar-a-Lago na Florydzie na początku kwietnia 2017 r. i sygnały o decyzji w sprawie rozpoczęcia intensywnej dyskusji na temat wzajemnych relacji handlowych wskazują, że region, a praktycznie świat, wchodzi w nowy etap kształtowania się stosunków między

${ }^{34}$ Philip Golub, East Asia Reemergence, Polity Press, Cambrige 2016, s. 142. 
głównymi graczami. Pierwsze sygnały mogą wskazywać na pewne zaskoczenie strony chińskiej na pozór niespójnymi, ale dynamicznymi i niekonwencjonalnymi działaniami nowego prezydenta USA. Dostępne już zręby wypracowywanego porozumienia handlowego wydają się sprzyjać pewnemu ograniczeniu olbrzymiego deficytu w handlu USA z Chinami ${ }^{35}$. Etap ten w relacjach amerykańsko-chińskich będzie zapewne charakteryzował się twardymi negocjacjami, okresowymi wzrostami napięcia i dalszymi nieoczekiwanymi wydarzeniami. W odniesieniu do USA istotą i głównym celem działań będzie obrona wpływów i pozycji, przede wszystkim przed wzrostem oddziaływania Chin. Polityka USA na szczeblu praktycznym obejmie także działania ofensywne, wymierzone we wpływy chińskie oraz wspieranie i mobilizowanie do takich działań swoich sojuszników w regionie, w tym szczególnie Japonii.

Jeżeli chodzi o sytuację w Azji Południowo-Wschodniej, administracja Obamy już od pewnego czasu starała się zacieśniać stosunki z ASEAN, czego ważnym etapem był szczyt USA-ASEAN w Sunnylands w Kalifornii w lutym 2016 r. i umocnienie strategicznego partnerstwa. W konsekwencji Kongres wydzielił środki, wprawdzie dość ograniczone - 250 mln dolarów, na wspieranie „bezpieczeństwa morskiego” takich partnerów jak Brunei, Indonezja, Malezja, Filipiny, Singapur, Wietnam, a także Tajwan ${ }^{36}$. Prezydent Trump wyraźnie zamierza powtórzyć i wzmocnić działania Obamy poprzez kolejne spotkanie na szczycie z przywódcami ASEAN, na którym będzie się starał osłabić wpływy Pekinu i przyciągnąć do współdziałania kraje Azji Południowo-Wschodniej (odbyło się już spotkanie ministrów spraw zagranicznych ASEAN z sekretarzem stanu Tillersonem).

USA szczególną wagę przywiązują do relacji z trzema krajami kontrolującymi cieśninę Malakka, czyli Singapurem, Malezją i Indonezją. Dobre stosunki i znaczne wpływy w tych krajach zapewniały amerykańskie interesy, a przede wszystkim bezpieczną komunikację przez najważniejszą w regionie (a może i na świecie) drogę morską. Dlatego symptomy ewolucji polityki zagranicznej Malezji z pewnością budzą zaniepokojenie. Przedmiotem zaniepokojenia jest też obecna polityka prezydenta Filipin, kraju tradycyjnie odgrywającego rolę bliskiego sojusznika Ameryki w Azji Południowo-Wschodniej. Należy więc oczekiwać stosownych działań amerykańskich, zmierzających do wyjaśnienia polityki zagranicznej obu tych krajów i zapewnienia utrzymania jej w akceptowalnych dla Waszyngtonu granicach. Włączenie Indonezji do azjatyckiej

${ }^{35}$ Robert Delaney, Zhenhua Lu, US Reach Trade Deal To Boot American Imports To China in Wake of Xi-Trump Summit, „South China Morning Post”,12 maja 2017.

36 Tom Miller, China's Asian Dream, Zed books, London 2017, s. 215. 
wizyty wiceprezydenta Pence'a w kwietniu 2017 r. wskazuje na poważne plany nowej administracji umocnienia stosunków z tym krajem.

Wbrew pierwszym zapowiedziom o zaostrzeniu polityki Waszyngtonu wobec Pekinu, w relacjach z Chinami na terenie Azji Południowo-Wschodniej raczej należy oczekiwać kombinowanego oddziaływania łączącego zachęty, naciski i perswazję polityczną z gestami natury demonstracji militarnej, jednak bez posuwania się do bezpośredniej konfrontacji zbrojnej. Amerykanie będą się starali w swoich poczynaniach ściśle współpracować z Japonią i w miarę możliwości z krajami regionu, a także wciągnąć w blokowanie Chin, również obecnością wojskową, inne państwa spoza regionu, takie jak Australia, Nowa Zelandia i Indie. Prawdopodobnie najchętniej występowaliby jako mocarstwo wspierające stanowiska państw regionu bezpośrednio pozostających w sporze $\mathrm{z}$ Chinami. Decydujące znaczenie dla stopnia i charakteru ich zaangażowania będą jednak miały prowadzone z Pekinem globalne negocjacje obu supermocarstw. Rozmowy amerykańsko-chińskie w sprawie kryzysu na Półwyspie Koreańskim mogą mieć także istotny wpływ na sytuację w Azji Południowo-Wschodniej.

2. Od czasu objęcia w Japonii stanowiska premiera (po raz drugi) Shinzō Abe podejmuje konsekwentne działania nakierowane na zmianę artykułu dziewiątego konstytucji, dotyczącego polityki obronnej i zreformowanie roli, zadań i wyposażenia japońskich sił zbrojnych. Działania te w roku 2016 nabrały rozmachu. Wynikało to z oceny, że sytuacja w zakresie bezpieczeństwa w Azji Północno-Wschodniej i szerzej w regionie Azji i Pacyfiku ewoluuje w kierunku zmiany układu sił, niekorzystnym dla Japonii. W ocenie japońskiej dzieje się to w związku z rosnącą potęgą Chin, ale również programem rakietowo-nuklearnym Korei Północnej, a także ponownym umacnianiem się Rosji. W powstających nowych warunkach Japonia musi zapewnić sobie możliwości „przeżycia” i stąd ostrożna, ale stała i konsekwentna rozbudowa potencjału militarnego. Przykładem tego w ostatnim okresie było zarówno rozpoczęcie formowania dużej jednostki piechoty morskiej na wzór amerykańskich marines, jak i intensyfikacja dyskusji i prac nad ofensywną bronią rakietową (rakiety manewrujące), na razie przeznaczoną do przenoszenia ładunków konwencjonalnych.

W sferze politycznej Shinzō Abe zdecydowanie działa na rzecz umocnienia sojuszu i współpracy z USA, zwiększa wyraźnie aktywność w sferze międzynarodowej, a równocześnie na obszarach azjatyckich i pozaazjatyckich próbuje bezpośrednio rywalizować, przede wszystkim w sferze gospodarczej, z wpływami chińskimi.

W regionie Azji Południowo-Wschodniej wszechstronna aktywność premiera Abe nabiera dalszej intensywności, a nawet agresywności. Obok oddziaływania na kraje regionu w sferze politycznej, naukowej, kulturowej i w zakresie 
kontaktów ludzkich szczególna uwaga skoncentrowana jest na problematyce gospodarczej i konkurowaniu z ekspansją chińską, na przykład w dziedzinie modernizacji i rozwoju kolejnictwa w Tajlandii, Malezji i Indonezji. Całkowicie nowym zjawiskiem jest rosnące zaangażowanie Japonii w szeroko rozumianą współpracę wojskową, czego Tokio dotychczas unikało. Szczególnie dotyczy to współpracy z takimi krajami jak Indonezja, Filipiny i Wietnam. Stało się to możliwe między innymi w związku ze zmianą zasad świadczenia pomocy rozwojowej, która od 2016 r., po uchwaleniu nowych przepisów, obejmuje także możliwości pomocy na cele wojskowe, niezwiązane bezpośrednio z działalnością bojową ${ }^{37}$. Zintensyfikowana została też japońska dyplomacja wojskowa, w postaci wizyt okrętów wojennych, wspólnych ćwiczeń i szkoleń na razie ograniczonych do misji ratunkowych i wsparcia, ale stopniowo coraz bardziej nabierających prawdziwie bojowego charakteru.

3. Niezależnie od rozwoju ogólnych tendencji w sytuacji światowej polityka Chin zarówno w całej Azji Wschodniej, jak i w Azji Południowo-Wschodniej pozostanie zgodna z kierunkiem nakreślonym przez prezydenta Xi Jinpinga w latach 2013-2014. Wiąże się to z wielkimi inicjatywami OBOR, gdzie szczególnie Morski Jedwabny Szlak XXI wieku stwarza nowe możliwości dla całego regionu Azji Południowo-Wschodniej i poszczególnych państw. Ważnym etapem w tej polityce było Forum Jedwabnego Szlaku w Pekinie 14-15 maja 2017 r., z udziałem przywódców 29 państw, wysokich przedstawicieli kilkudziesięciu innych państw (w tym USA i Japonii) oraz najważniejszych organizacji międzynarodowych. Strona chińska, w jeszcze większym stopniu, będzie się posługiwać takimi instrumentami jak Fundusz Jedwabnego Szlaku i Azjatycki Bank Inwestycji Infrastrukturalnych, a także Nowy Bank Rozwoju, aby utrzymać i rozwijać zainteresowanie współpracą z Chinami i ich przedsiębiorstwami.

Jeżeli w relacjach bezpośrednich z partnerem amerykańskim wysoce prawdopodobne jest, na odcinku handlu i gospodarki, zajęcie początkowo pozycji elastycznej i umiejętne operowanie nieznacznymi taktycznymi ustępstwami oraz „grą na czas”, o tyle w średniej, a zwłaszcza dłuższej perspektywie należy oczekiwać zdecydowanej konkurencji na tej płaszczyźnie relacji i na wszystkich innych.

W Azji Południowo-Wschodniej, a zwłaszcza wobec krajów basenu Morza Południowochińskiego, działania chińskie będą prawdopodobnie skierowane na wyeliminowanie, a przynajmniej osłabienie sojuszy i związków dwustronnych tych krajów z USA. Stosowane będą zróżnicowane taktyki - od eskalacji napięć

${ }^{37}$ Cai Hong, Japan's Development Assistance Has Become a Security Policy Tool, „China Daily", 27 marca 2017. 
wokół sporów terytorialnych, między innymi w celu wykazywania słabości gwarancji amerykańskich, po wciąganie w nowe atrakcyjne formy współpracy.

Działania Pekinu będzie uzupełniać ofensywa soft power oparta na całym zespole środków, takich jak powoływanie nowych instytutów i klas Konfucjusza, szeroki program stypendialny dla studentów i naukowców, programy szkolenia zawodowego, kontakty ludności i inne zachęty do współpracy. Program ten będzie coraz mocniej wspierany i uzupełniany przez ofensywę wyspecjalizowanych mediów nastawionych na oddziaływanie na zagranicę, jak programy telewizyjne i radiowe, oraz przejmowanie kontroli nad mediami lokalnymi. Skuteczności tych działań sprzyjać będzie zarówno stosunkowo niewielkie w porównaniu ze społeczeństwami Zachodu - nasycenie lokalnych społeczności takimi działaniami, jak i możliwość korzystania w niektórych krajach z życzliwego wsparcia chińskich mniejszości tam zamieszkałych (choć może to grozić negatywnymi konsekwencjami dla tych społeczności).

Równolegle z powyższymi działaniami należy oczekiwać utrzymania, a nawet stopniowego zwiększania chińskiej obecności w regionie, w tym na terenach spornych. Obejmować to będzie zarówno zwiększanie sił wojskowych i budowę nowoczesnych instalacji, na przykład na wyspach i rafach Spratly, czy rozbudowę centrum administracyjnego i swego rodzaju osiedla na jednej z Wysp Paracelskich, co nadaje chińskiej obecności cechy normalności. Na obszarach morskich wykorzystywane będą, obok floty wojennej, jednostki straży przybrzeżnej, platformy wiertnicze, a nawet masowo użyte zmobilizowane cywilne kutry rybackie. Działania będą jak dotychczas na ogół ostrożne, nakierowane na „miękkie” przejęcie kontroli nad najważniejszymi obiektami i tworzenie „faktów dokonanych”, co nie wyklucza w razie potrzeby podejmowania kroków zdecydowanych, z użyciem siły włącznie.

Równocześnie prowadzone będą działania polityczne na płaszczyźnie wielostronnej. Przykładem jest wypracowanie w wyniku żmudnych negocjacji Chin z ASEAN pierwszej roboczej wersji schematu Kodeksu postępowania na Morzu Południowochińskim. Warto wspomnieć, że decyzję o rozpoczęciu prac podjęto w 2002 r., a proces negocjacyjny był wielokrotnie przerywany. Wydaje się, że strona chińska będzie grać na czas. W pewnych warunkach może jednak się zgodzić na sformułowania zalecające wstrzymanie instalowania na wyspach i rafach tego morza broni ofensywnych przy zachowaniu broni defensywnych (szeroko rozumianych), zabezpieczających w pełni jej interesy. W relacjach dwustronnych szeroko stosowane będą bardzo korzystne oferty współpracy, a nawet współdziałania wobec krajów, instytucji i środowisk nieufnych w stosunku do Chin. Takie próby mają miejsce chociażby wobec filipińskich sił zbrojnych, tradycyjnie mocno powiązanych z USA. 
W konsekwencji należy się liczyć z niemal nieuchronnym stałym umacnianiem się pozycji i wpływów Chin w Azji Południowo-Wschodniej kosztem przede wszystkim wpływów Zachodu, w tym zwłaszcza będącej w kryzysie Unii Europejskiej, częściowo USA, a w najmniejszym stopniu Japonii zdecydowanie broniącej swego „stanu posiadania”. Możliwe będzie nieznaczne umocnienie wpływów Indii i w przypadku niektórych krajów także Rosji. Na tempo tych procesów z pewnością wpłynie ewolucja napięć, jakie się pojawiły ostatnio w Azji Północno-Wschodniej w związku z programem zbrojeniowym realizowanym przez Koreę Północną. Na rozwój sytuacji w regionie znacząco też może oddziaływać radykalny islam, o ile w krajach regionu nie będą podejmowane odpowiednie kroki neutralizujące to zagrożenie.

\section{Summary}

\section{The USA and Southeast Asia: a new deal}

The beginning of XXI century is characterized by the rise of the role of East Asia in the contemporary world. The rivalry of great powers embraced all region, included Southeast Asia, which for a long time was at the forefront of development and regional integration initiatives, especially with the ASEAN. It became the area of interventions and influences of major external powers such as the United States, China, India, Japan, Australia, and the EU and Russia. Unfortunately also old local animosities included unresolved territorial disputes and new challenges like terrorism and pandemics, affect Southeast Asia. The American presidential election campaign in 2016 and particularly campaign of Donald Trump exerted great influence on situation in Southeast Asia. Some controversial decisions of Donald Trump such as withdrawal from Trans Pacific Partnership and the absence of the clear policy in the region, after the policy of "pivot/rebalance" of president Obama, almost completely changed political situation in Southeast Asia. The immediate consequence is the rise of the Chinese position in the area and extraordinary activation of diplomacy of Japan, Vietnam and some other countries, making attempt to stop Chinese influence. The political situation in the region turned more dynamic, unforeseeable and complicated. The countries of Southeast Asia sooner or later will face the crucial choice between the United States and China. 


\section{Bibliografia}

1. Amy Chew A., Mahathir Takes Swipe at Najib Over Malaysia's Stupid'Chinese Business Deal, „South China Morning Post”, 27 czerwca 2016.

2. Bonnet F.X., Quand Manille manoeuvre, „Le Monde diplomatique”, maj 2017.

3. Cai Hong, Japan's Development Assistance Has Become a Security Policy Tool, „China Daily”, 27 marca 2017.

4. Delaney R., Zhenhua Lu, US Reach Trade Deal To Boot American Imports To China in Wake of Xi - Trump Summit, „South China Morning Post”, 12 maja 2017.

5. Deng Yuwen, In the Trump Era, We Can't Rule Out War Between China and the US, Whether Over Trade or Security, ,South China Morning Post”, 10 lutego 2017.

6. Gilles P., Donald Trump se rallie à la politique d'une seule Chine, „Le Monde", 10 lutego 2017.

7. Golub P., East Asia Reemergence, Cambrige 2016.

8. Indonesia, Japan To Deepen Defence Ties Amid China Challenge, „South China Morning Post", 15 stycznia 2017.

9. Kruczkowska M., Tokio uktada się z Donaldem Trumpem, „Gazeta Wyborcza", 7 lutego 2017.

10. Liu Zhen, US Navy Carrier Group Begins South China Sea Patrols, „South China Morning Post", 19 lutego 2017.

11. Mandraud I., Le président philippin demande des armes à son homologue russe Vladimir Poutine, „Le Monde”, 24 maja 2017.

12. Miller T., China's Asian Dream, London 2017.

13. Mo Jingxi, Vietnam Dredging on Chinese Reef It Occupies, „China Daily”, 11-12 października 2016.

14. Morze Południowochińskie: serce potencjalnego konfliktu w Azji, Centrum Stosunków Międzynarodowych, Warszawa 2016.

15. Pedroletti B., Philip B., Le premier ministre malaisien joue la carte chinoise, „Le Monde”, 2 listopada 2016.

16. Pei M., Trump's Rise Leaves China Ideologically Safe but Facing Graver Security Risks, ,South China Morning Post”, 12 lutego 2017.

17. Pflimlin E., Tokyo paie beaucoup plus que ne l'imagine Trump pour son alliance avec les Etats - Unis, „Le Monde”, 17 listopada 2016.

18. Philip B., Le Laos, pays enclave et regime repressive, „Le Monde”, 8 września 2016.

19. Pocket World in Figures, „,The Economist” 2017. 
20. Report On The Growing US Military Presence in The Asia-Pacific Region, „China Daily”, 26 listopada 2016.

21. Shambaugh D., In a Fundamental Shift, China and the US Are Now Engaged in All-Out Competition, „South China Morning Post”, 11 czerwca 2015.

22. Shi Jiangtao, Future of South China Sea Disputes Depends on Washington, Says China 's Legislature Spokeswomen, „South China Morning Post”, 4 marca 2017.

23. Szczudlik J., Chińska perspektywa stosunków z USA za prezydentury Donalda Trumpa, „Biuletyn PISM”, 16 stycznia 2017, nr 4.

24. White H., With Their Threats To China, Trump and Tillerson Are Making Rookie Blunders That Will Only Hurt US Credibility, „South China Morning Post", 17 stycznia 2017.

25. Wong C., Chinese Diplomat Tells Singapore to Stay out of South China Sea Disputes, „South China Morning Post”, 16 sierpnia 2016.

26. Wong C., Indonesian Leader Widodo's Emphasis on Development Boosts China Ties, ,South China Morning Post”, 26 sierpnia 2016.

27. Xu Lushan, US Resumes Its Provocative Action in Sea, „China Daily”, 22 lutego 2017.

28. Zhang Yunbi, Chen Weihua, Beijing To Push Talks on Regional Free Trade Pacts, „China Daily”, 25 stycznia 2017.

29. Zhao Huanxin, Trump Holds First Meeting With Senior Chinese Official, „China Daily", 28 lutego 2017.

30. Zhou V., Trump on Asia: What He's Said and Where He Stands, „South China Morning Post", 10 listopada 2016. 